\title{
Effects of immunosuppression on herpes simplex virus growth in lymphocytes of patients with connective tissue diseases
}

\author{
P. HOLlingWORTh, W. HYLTON, B. K. PELTON, ANDA. M. DENMAN \\ From the Clinical Research Centre and Northwick Park Hospital, Watford Road, Harrow, Middlesex HA1 3UJ
}

SUMMARY The growth of herpes simplex virus (HSV) was measured in blood lymphocytes isolated from patients with connective tissue diseases receiving immunosuppressive drugs. Whereas lymphocytes from such patients were frequently nonpermissive for HSV before treatment, they became permissive in most patients after treatment. The exception was the persistence of nonpermissiveness in lymphocytes of treated patients whose disease was associated with malignant disease.

In an attempt to obtain indirect evidence for a viral aetiology of inflammatory connective diseases the growth of viruses in lymphocytes from patients with these disorders has been compared with that in lymphocytes from normal donors or patients with other diseases. We reasoned that infected lymphocytes might be refractory to superinfection by related viruses (virus interference). ${ }^{12}$ It was found that herpes simplex virus type 1 (HSV) commonly failed to grow in blood lymphocytes from patients with such diseases or in lymphocytes isolated from rheumatoid synovial effusions, but this nonpermissiveness was variable and unpredictable. There was also some indication that HSV grew to normal titres in blood lymphocytes of patients receiving steroids or cytotoxic drugs. ${ }^{13}$ Since reversal of nonpermissiveness by these drugs might help to explain the abnormal growth pattern, the effects of immunosuppressive drugs on HSV growth in lymphocytes were systematically examined in patients with connective tissue diseases receiving these agents in a controlled trial. ${ }^{4}$

\section{Materials and methods}

\section{PATIENTS}

Blood samples were obtained from a total of 111 patients with systemic lupus erythematosus (SLE), polyarteritis, dermatomyositis, and Behçet's syn-

Accepted for publication 5 May 1982

Correspondence to Dr A. M. Denman, Clinical Research Centre, Watford Road, Harrow, Middlesex HA1 3UJ drome, diagnosed by accepted criteria, ${ }^{4}$ who were not receiving steroids or cytotoxic drugs when first studied. The dermatomyositis in 6 patients and polyarteritis in 1 patient was associated with malignant disease. All patients had active disease. ${ }^{4}$ Control blood samples were obtained from age and sex matched laboratory staff. ${ }^{3}$

Forty-four patients received steroids alone or in combination with cytotoxic agents (Table 1). The methods of assessing their clinical response $e^{4}$ and, for Behçet's syndrome ${ }^{5}$ have been described. Serial blood samples for assaying HSV growth were taken at 3-monthly intervals or more frequently for periods ranging from 9 to 60 months in most patients.

The clinical indications for early treatment precluded a long period of study before treatment. However, serial samples for virus assay were obtained

Table 1 Treatment regimens

\begin{tabular}{|c|c|}
\hline \multirow{3}{*}{ Initial phase: } & Intensive immunosuppression \\
\hline & $\begin{array}{l}\text { antilymphocyte globulin } 750 \mathrm{mg} \text { i.v. } \\
\text { for } 15 \text { days, azathioprine } 2.5 \mathrm{mg} / \mathrm{kg} / \text { day }\end{array}$ \\
\hline & prednisolone $150 \mathrm{mg} /$ day \\
\hline \multirow[t]{3}{*}{ Maintenance phase: } & azathioprine $2.5 \mathrm{gm} /$ day, \\
\hline & $\begin{array}{l}\text { prednisolone } 20 \mathrm{mg} / \text { day adjusted } \\
\text { according to disease activity }\end{array}$ \\
\hline & $\begin{array}{l}\text { Steroids only } \\
60 \mathrm{mg} / \mathrm{day} \text { initially reduced over } \\
10 \text { days to } 20 \mathrm{mg} / \text { day and thereafter } \\
\text { adjusted according to disease activity }\end{array}$ \\
\hline
\end{tabular}

See reference 4 for details. 
from 8 patients with Behçet's syndrome and 2 patients with SLE who received neither steroids nor cytotoxic agents during a 5-year period of observation.

\section{MMUNOLOG ICAL METHODS}

Isolation of mononuclear cells. Mononuclear cells were isolated and cultured by standard methods. ${ }^{2}$ All preparations contained not less than $80 \%$ lymphocytes judged by morphology on slide centrifuge preparations and conventional markers. This degree of contamination by other cell types does not interfere with HSV growth. ${ }^{6}$

Mitogen stimulation. Mononuclear cells at $10^{6}$ cells $/ \mathrm{ml}$ were stimulated with phytohaemagglutinin (PHA), $0 \cdot 8 \mu \mathrm{g} / 10^{6}$ cells. The response was assessed by ${ }^{14} \mathrm{C}$ thymidine uptake over an 18 -hour period 48 hours after mitogen stimulation.

Ig production. IgM and IgG production by lymphocytes stimulated with pokeweed mitogen was measured by radioimmunoassay using antisera purified by immunoadsorption. ${ }^{7}$ Ig production was measured in cultures of unseparated lymphocytes and of mixed $\mathrm{T}$ and $\mathrm{B}$ lymphocyte populations cultured at varying ratios from $10 \mathrm{~T}$ : $1 \mathrm{~B}$ cell to $10 \mathrm{~B}: 1 \mathrm{~T}$ cell. Separation was achieved by standard techniques.?

\section{VIROLOGICAL METHODS}

Virus stock. The HFEM strain of herpes simplex virus type 1 was propagated in chick embryo fibroblasts.

Infection of mononuclear cells. Mononuclear cells at a concentration of $10^{6} \mathrm{cells} / \mathrm{ml}$ were stimulated with PHA and infected with HSV after 24 hours' culture at a multiplicity of infection of $0 \cdot 1$ virus particle per cell. The cell suspension was transferred to flat bottomed glass vials $0.3 \times 10^{6} \mathrm{cells} / \mathrm{vial}$, and triplicate samples were frozen at $-70^{\circ} \mathrm{C}$ on day 0 to day 5 after infection. ${ }^{7}$

Measurement of virus titres. The suspensions of mononuclear cells were repeatedly frozen and thawed and virus was titrated by the semimicro plaque assay method using owl monkey kidney monolayers. ${ }^{6}$

Definition of normal and abnormal HSV growth. The range of HSV growth in lymphocytes from normal donors was $4 \cdot 2-6 \cdot 4 \log$ plaque-forming units $(\mathrm{PFU}) / 1 \cdot 0 \times 10$ cultured cells and such cultures are termed 'permissive'. Conversely lymphocyte cultures from patients with connective tissue diseases which failed to support the growth of HSV to normal titres are termed 'nonpermissive'.

STATISTICAL ANALYSIS

In order to assess the effects of steroids or intensive immunosuppression on HSV growth in lymphocytes, it was necessary to take spontaneous changes in growth patterns into account. The mean HSV titre of serial determinations during treatment was calculated to determine the percentage of patients in each disease category who became permissive for HSV compared with the number who were permissive before treatment. This increase in permissiveness was compared by Student's $t$ test with the percentage of untreated patients who became permissive over a similar period of observation.

\section{Results}

Nonpermissiveness for HSV was observed in several patients in each disease category (Fig. 1, Table 2).

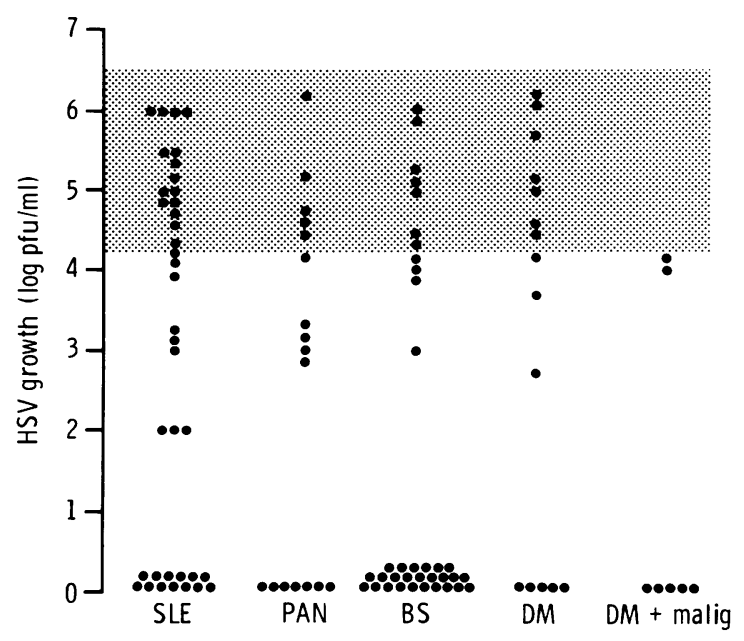

Fig. 1 HSV growth in lymphocytes of patients with connective tissue diseases. Shaded area indicates range of repeated determinations in 30 normal controls. PAN: polyarteritis. BS: Behçet's syndrome. DM: dermatomyositis. Behçet's syndrome data include some of the results published in reference 3.

Table 2 Numbers of patients whose lymphocytes showed permissiveness and nonpermissiveness.

\begin{tabular}{|c|c|c|c|}
\hline & \multirow{2}{*}{$\frac{\text { Infectivity titres }}{<4 \cdot 2}$} & \multirow{2}{*}{$\frac{(\log / m l)}{>4 \cdot 2}$} & \multirow[t]{2}{*}{$p$} \\
\hline & & & \\
\hline $\begin{array}{l}\text { Controls } \\
\text { Systemic lipus }\end{array}$ & 0 & 30 & \\
\hline erythematosus & 20 & 17 & $<0.001$ \\
\hline Polyarteritis nodosa & 11 & 5 & $<0.001$ \\
\hline Dermatomyositis & 7 & 8 & $<0.001$ \\
\hline Behçet's syndrome & 28 & 8 & $<0.001$ \\
\hline Patients with malignancy & 7 & 0 & $<0.001$ \\
\hline
\end{tabular}


Table 3 Effects of immunosupression on the growth of HSV in lymphocytes of patients with connective tissue disease

\begin{tabular}{|c|c|c|c|c|c|c|}
\hline \multirow[t]{2}{*}{ Patient category } & & \multicolumn{2}{|c|}{ Before treatment } & \multicolumn{2}{|c|}{ During treatment } & \multirow[t]{2}{*}{$p$} \\
\hline & & Permisive & Nonpermisive & Permisive & Nonpermisive & \\
\hline All patients & $\begin{array}{l}\text { Group } 1 \\
\text { Group } 2\end{array}$ & $\begin{array}{r}0 \\
14\end{array}$ & $\begin{array}{r}22 \\
0\end{array}$ & $\begin{array}{l}22 \\
14\end{array}$ & $\begin{array}{l}0 \\
0\end{array}$ & $\begin{array}{l}<0.001 \\
<0.005\end{array}$ \\
\hline SLE & $\begin{array}{l}\text { Group } 1 \\
\text { Group } 2\end{array}$ & $\begin{array}{l}0 \\
2\end{array}$ & $\begin{array}{l}5 \\
0\end{array}$ & $\begin{array}{l}5 \\
2\end{array}$ & $\begin{array}{l}0 \\
0\end{array}$ & $\begin{array}{l}<0.001 \\
\text { NS }\end{array}$ \\
\hline Polyarteritis & $\begin{array}{l}\text { Group } 1 \\
\text { Group } 2\end{array}$ & $\begin{array}{l}0 \\
3\end{array}$ & $\begin{array}{l}5 \\
0\end{array}$ & $\begin{array}{l}5 \\
3\end{array}$ & $\begin{array}{l}0 \\
0\end{array}$ & $\begin{array}{l}<0.001 \\
\text { NS }\end{array}$ \\
\hline Dermatomyositis & $\begin{array}{l}\text { Group } 1 \\
\text { Group } 2\end{array}$ & $\begin{array}{l}0 \\
2\end{array}$ & $\begin{array}{l}5 \\
0\end{array}$ & $\begin{array}{l}5 \\
2\end{array}$ & $\begin{array}{l}0 \\
0\end{array}$ & $\begin{array}{l}<0.001 \\
\text { NS }\end{array}$ \\
\hline Behçet's syndrome & $\begin{array}{l}\text { Group } 1 \\
\text { Group } 2\end{array}$ & $\begin{array}{l}0 \\
7\end{array}$ & $\begin{array}{l}7 \\
0\end{array}$ & $\begin{array}{l}7 \\
7\end{array}$ & $\begin{array}{l}0 \\
0\end{array}$ & $\begin{array}{l}<0.001 \\
<0.005\end{array}$ \\
\hline Untreated patients & & 6 & 4 & 1 & 9 & - \\
\hline
\end{tabular}

Group 1: permissive for HSV before treatment.

Group 2: nonpermissive for HSV before treatment.

Statistical comparison with HSV titres in untreated patients.

Sequential cultures from the 10 patients who remained untreated showed unpredictable alteration between permissiveness and nonpermissiveness, each phase lasting from several months to as long as 2.8 years. Virus growth in simultaneous cultures from control donors was invariably within the normal range.

\section{EFFECTS OF TREATMENT ON HSV GROWTH}

Three patterns of HSV growth in lymphocytes could be distinguished after treatment.

Group (1). Patients with nonpermissive lymphocytes before treatment (Table 3). Lymphocyte cultures from all 22 patients in this group became permissive for HSV within 3 months of starting treatment and remained so over a period of observation ranging from 9 to 41 months irrespective of changes in treatment or minor fluctuations in disease activity. The pattern was similar whether the patients received steroids alone or intensive immunosuppression. Mean HSV titres were consistently higher than those obtained in lymphocytes cultured from untreated patients. An example of this pattern of response is given in Fig. 2.

Group (2). Patients with permissive lymphocytes for HSV growth before treatment (Table 3). Lymphocytes from 14 patients which were permissive for HSV before treatment remained consistently so during a period of observation ranging from 9 to 44 months. Again this permissiveness was sustained whether the treatment consisted of steroids alone or intensive immunosuppression. In this group as a whole virus growth was also significantly greater than that observed in untreated patients (Table 2), but in

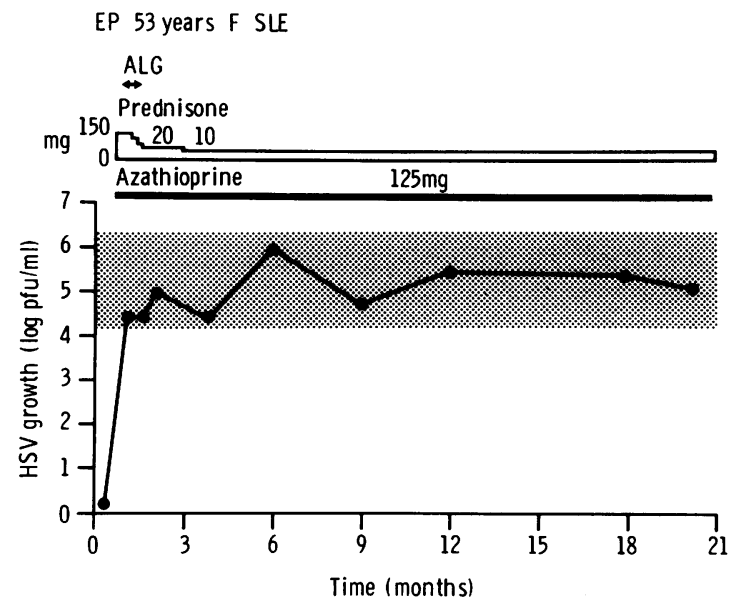

Fig. 2 Reversal of nonpermissiveness for $\mathrm{HSV}$ by immunosuppression. Shaded area indicates control range.

terms of individual diseases this significance extended only to patients with Behçets's syndrome. This pattern of response is illustrated in Fig. 3.

Group (3). Patient with connective tissue disease associated with malignancy (Table 4). In the group of connective tissue diseases associated with malignancy 6 patients received intensive immunosuppression and the remaining patient prednisolone alone. Lymphocytes from all patients were nonpermissive initially and remained so for periods up to 3 years even though in all cases the connective tissue disease remitted. This sequence of events is illustrated in Fig. 4. HSV titres in this group were significantly lower 
HB 44 years $m$ Behçet's syndrome

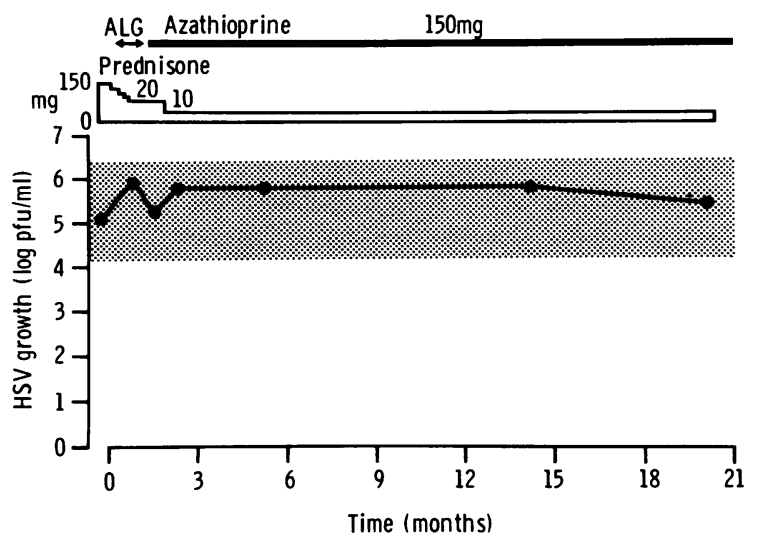

Fig. 3 Persistent permissiveness for HSV after immunosuppression. Shaded area indicates control range.

than those noted in treated patients of groups 1 and 2 whose diseases were not associated with malignancy $(p<0 \cdot 001)$. However, these did not differ significantly from the HSV titres in patients with untreated connective tissue diseases not associated with malignancy (Table 2). Single lymphocyte samples from 6 patients with carcinoma of the breast or bronchus but without inflammatory connective tissue were assayed during this study, and all supported virus growth to titres within the normal range $4 \cdot 2-6 \cdot 4 \log \mathrm{HSV} / \mathrm{ml}$.

Influence of treatment schedule on HSV growth in lymphocytes. Mean HSV titres were $0.26 \mathrm{log} / \mathrm{ml}$ higher in lymphocytes of patients receiving intensive immunosuppression than in lymphocytes of patients receiving steroids alone. The $95 \%$ confidence limits are 0.58 to -0.06 . This is a statistically significant different $(\mathrm{p}<0 \cdot 001)$.

Lymphocyte function. HSV grows only in stimulated lymphocytes responding to mitogens such as PHA. ${ }^{1}$ However, no correlation was found between ${ }^{14} \mathrm{C}$-thymidine incorporation and HSV virus titres. In
EF 68 years $m$ polyarteritis

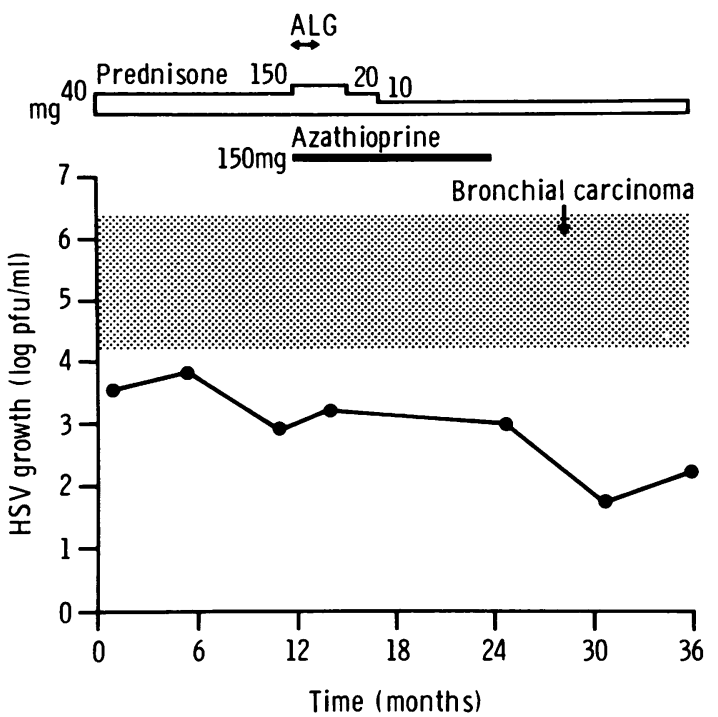

Fig. 4 Failure of immunosuppression to reverse nonpermissiveness for $H S V$ in a patient with polyarteritis and malignant disease. Shaded area indicates control range.

many instances lymphocytes which showed good proliferative responses to PHA were nonpermissive, while other cultures supported virus growth normally despite a poor proliferative response. Since HSV grows predominantly in inducer $\mathrm{T}$ lymphocytes, ${ }^{8}$ inducer $\mathrm{T}$ cell function was assayed by measuring $\mathrm{Ig}$ production in cultures stimulated with PWM. However there was no correlation between the Ig produced at optimal ratios of $T$ and $B$ cells and HSV growth in PHA-stimulated lymphocytes isolated from the same blood samples $(r=0 \cdot 2)$.

\section{Discussion}

These results show that immunosuppressive treatment with steroids alone or in combination with

Table 4 Serial studies on HSV replication in lymphocytes of patients with malignancy and associated connective tissue disease

\begin{tabular}{|c|c|c|c|c|c|c|c|}
\hline Connective tissue disease & $D M$ & $D M^{*}$ & $P A N$ & $D M$ & $D M$ & $D M$ & $D M$ \\
\hline Primary tumour & Pancreas & Breast & Lung & Breast & Breast & Breast & Breast \\
\hline Pretreatment virus titre $(\log \mathrm{HSV} / \mathrm{ml})$ & 0 & $2 \cdot 7$ & $4 \cdot 0$ & 0 & 0 & 0 & $4 \cdot 1$ \\
\hline Mean of subsequent titres (log $\mathrm{HSV} / \mathrm{ml})$ & $1 \cdot 8$ & $3 \cdot 4$ & $3 \cdot 5$ & $3 \cdot 7$ & 3-7 & $3 \cdot 8$ & $3 \cdot 5$ \\
\hline Period of study (months) & 9 & 12 & 36 & 9 & 3 & 3 & 3 \\
\hline
\end{tabular}

Patients received either prednisolone or intensive immunosuppression.

*This patient remains well off all treatment 7 years after mastectomy. Her lymphocytes now support normal viral growth.

The remaining patients died of malignancy. At no stage did their lymphocytes support HSV growth to normal titres $(>4 \cdot 2$ log PFU/ml), although their connective tissue disease was in remission and they were receiving prednisolone or intensive immunosuppression.

DM: dermatomyositis. PAN: polyarteritis. 
cytotoxic drugs restores a normal pattern of HSV growth in blood lymphocytes of patients with connective tissue diseases. Since lymphocytes from untreated patients show an unpredictable variation between permissiveness and nonpermissiveness, ${ }^{1}$ it was important to confirm that the reversion to consistent permissiveness was attributable to treatment and not to spontaneous variation. The normal pattern of HSV growth in treated patients persisted through the study in contrast with the fluctuations noted in cultures from patients with the same disorders who were not receiving steroids or cytotoxic drugs.

While these studies were originally initiated in a search for latent virus infection of lymphocytes, there are other possible explanations for the results. It is apparent from studies of blood lymphocytes from patient's with Behçet's syndrome ${ }^{3}$ and lymphocytes isolated from rheumatoid synovial effusions ${ }^{2}$ that nonpermissiveness may reflect a form of host antiviral immunity. Nonpermissive lymphocyte cultures contain lymphocytes which are potentially susceptible to infection by HSV, but these are protected from HSV infection by other lymphocyte populations in the cultures. The mechanism of this protection has not been elucidated. Intermittent nonpermissiveness for HSV replication reversible by steroid therapy might at first sight seem attributable to interferon, since interferon is intermittently detectable in the serum of patients with inflammatory connective tissue diseases. ${ }^{9}$ Nevertheless this seems an unlikely explanation, since interferon production in lymphocyte cultures permissive for HSV did not differ significantly from that detected in nonpermissive cultures. ${ }^{6}$ Furthermore the inhibition of virus growth is dependent upon cell to cell contact and has not been shown to involve interferon or other soluble antiviral factors. Both $\mathrm{K}$ and NK cells are susceptible to cytotoxic drugs, but these are unlikely to be responsible for the inhibition of HSV growth, since the inhibitory cells confer protection from infection only on autologous cells and not on $\mathrm{T}$ cells from other histoincompatible donors. ${ }^{6}$

Even after antigenic stimulation only a small percentage of inducer $T$ cells in normal blood are permissive for HSV. ${ }^{8}$ The nonpermissiveness for HSV in connective tissue diseases could have been accounted for either by a paucity of circulating susceptible cells or by a defective response to PHA corrected by steroids or cytotoxic drugs. However, there was no correlation between the response to PHA measured by standard techniques and the ability of stimulated cells to support the growth of HSV. Similar observations have been made with respect to the nonpermissiveness for HSV of lymphocytes isolated from rheumatoid synovial effusions ${ }^{2}$ and the blood of patients with Behçet's syndrome. ${ }^{3}$ Indeed a variety of control experiments have shown that the artificial dilution of the susceptible cells in normal blood cultures by admixture with cells incapable of supporting virus growth does not depress virus growth until the concentration of permissive cells has been reduced to a concentration far below that produced by disease or immunosuppressive drugs. ${ }^{6}$ An attempt was made to assay inducer $\mathrm{T}$ cell function more precisely by inducing polyclonal $\mathrm{IgG}$ production in combinations of $\mathrm{T}$ and B lymphocytes. No correlation was observed between permissiveness and nonpermisiveness for $\mathrm{HSV}$ and IgG production by lymphocytes from the same blood sample. It is unlikely, therefore, that a deficiency of susceptible cells explains the variation in virus growth. Thus these results are still compatible with the notion that immunosuppression eliminates virus infected cells or ablates a form of host antiviral immunity.

The patients in this study received steroids alone or in combination with other immunosuppressive drugs as part of a controlled therapeutic trial. ${ }^{4}$ The results showed that immunosuppressive drugs are more effective than steroids alone in controlling the disease manifestations of polyarteritis, Behçet's syndrome, and dermatomyositis. It was possible that the reversal on nonpermissiveness for HSV growth might be related to the extent of clinical remission. HSV titres in lymphocytes cultured from patients receiving intensive immunosuppression were indeed statistically higher than those obtained in cultures from patients receiving steroids alone, but this difference was small. However, in contrast with the observations in patients without associated malignancy a normal pattern of HSV growth was not restored in patients with malignant disease. There are no obvious explanations for this finding. Nonpermissiveness for HSV persisted despite clinical remission of the connective tissue disease. Since HSV growth was normal in patients with carcinomas not associated with connective tissue disease, this form of malignant disease is not itself associated with nonpermissiveness. The range of lymphocyte responses to PHA and inducer T cell function was comparable to that observed in the other groups. The patients with malignant disease were not more susceptible to secondary infections than were the other patients, ${ }^{4}$ so that it is unreasonable to attribute the persistent nonpermissiveness to generalised immunodeficiency. Possibly lymphocytes from these patients fail to support the growth of HSV for reasons unrelated to the nonpermissiveness seen in connective tissue disorders in general, and indeed reactivation of other latent viruses secondary to malignant disease could theoretically account for this observation. The failure of lymphocytes from steroid treated patients with connective tissue disorders in association with malig- 
nancy to support HSV replication may have clinical diagnostic value.

The authors are grateful to Dr David Hill for statistical analysis. They also thank Drs B. M. Ansell, J. M. Gumpel and D. S. Smith for permission to study some of the patients included in this study and Hoechst Pharmaceuticals who donated the anti-lymphocyte globulin. Finally they are extremely grateful to Mrs Jenny O'Connor for her help in preparing this manuscript.

\section{References}

1 Denman A M, Pelton B K, Appleford D J A, Kinsley M. Virus infections of lymphoreticular cells and auto-immune diseases. Transplant Rev 1979; 31: 79-115.

2 Appleford D J A, Denman A M. Fate of herpes simplex virus in lymphocytes from inflammatory joint effusions. I. Failure of the virus to grow in cultured lymphocytes. Ann Rheum Dis 1979; 38: 443-9.

3 Denman A M, Fialkow P J, Pelton B K, et al. Lymphocyte abnormalities in Behçet's syndrome. Clin Exp Immunol 1980; 42: 175-85.
4 Hollingworth P, de Vere Tyndall A, Ansell B M et al. Intensive immunosuppression versus prednisolone in the treatment of connective tissue diseases. Ann Rheum Dis in press.

5 Denman A M, Hollingworth P, Webster A D B, Pelton B K, Rhodes E L. Failure of transfer factor in the treatment of Behçet's disease: a double-blind trial. In: Lehner T, Barnes C G, eds. Behçet's Syndrome New York and London. Academic Press, 1979: 277.

6 Appleford D J A, Denman A M. Fate of herpes simplex virus in lymphocytes from inflammatory joint effusions. II. Mechanisms of nonpermissiveness. Ann Rheum Dis 1979; 38: 450-5.

7 Pelton B K, Imrie R C, Denman A M. Susceptibility of human lymphocyte populations to infection by herpes simplex virus. Immunology 1977; 32: 803.

8 Pelton B K, Duncan I B, Denman A M. Herpes simplex virus depresses antibody production by affecting T-cell function. Nature 1980; 284: 176-7.

9 Hooks J J, Moutsopoulos H M, Geis S A, Stahl N I, Decker J L, Notkins A L. Immune interferon in the circulation of patients with autoimmune disease. $N$ Engl J Med 1979; 301: 5.

\section{Book review}

Epidemiology of Musculoskeletal Disorders. By J. L. Kelsey. Pp. 229. £25•00. Oxford University Press: Oxford. 1983.

This is a relatively short book reviewing the epidemiology of a wide range of musculoskeletal disorders from spina bifida and clubfoot to dislocation of the shoulder and neoplasms of bone. Only one of the 9 chapters covers the arthritic disorders, and thus there is probably more of interest to the orthopaedic surgeon than the rheumatologist. Well written and easily readable, the book has a comprehensive list of references at the end of each chapter ( 342 in the chapter on arthritic disorders). In the preface the author admits that the selection of subjects reflects in part her own interests and expertise. There are particularly comprehensive sections on Perthe's disease, slipped femoral epiphysis, and scoliosis.

A general criticism is the lack of informed discussion about the merits or otherwise of some of the speculative suggestions made from epidemiological studies. The author perhaps glosses over the difficulties of doing such work in this area. There are also some surprising omissions. First there is no mention of Lyme arthritis despite the fact that the author is from Yale; neither is there more than cursory mention of the epidemiology of reactive arthritis after enteropathic infection-both areas of major interest in the understanding of the epidemiology of rheumatic disorders. There is also no information on temporal arteritis/ polymyalgia rheumatica or systemic lupus, both of which have been the subject of epidemiological study and provided findings of interest.

The intended readership of this book is not readily apparent, but it has enough of interest, especially given the bibliography, to justify its place in an orthopaedic/ rheumatological departmental library.

A. J. SILMAN 